\title{
EDITORIAL
}

\section{Recent Studies on the Insulin-Secreting Porosome Complex Provide Potential Therapeutic Applications in the Treatment of Diabetes}

\author{
Lloyd L. Anderson*
}

Department of Animal Science, College of Agriculture and Life Sciences and Department of Biomedical Sciences, College of Veterinary Medicine, Iowa State University, Ames, IA 50011-3150, USA

*Corresponding author:

Lloyd L. Anderson, PhD, Iowa State University, 2356 Kildee Hall, Ames, Iowa 50011-3150, Phone: (515) 294-5540; Fax: (515) 294-4471; E-mail: llanders@iastate.edu

Submitted: Dec. 1, 2015; Revised: Dec. 2, 2015; Accepted: Dec. 3, 2015; Published: Dec. 4, 2015;

Citation: Anderson LL. Recent Studies on the Insulin-Secreting Porosome Complex Provide Potential Therapeutic Applications in the Treatment of Diabetes. Discoveries 2015, Oct-Dec; 3(4): e51. DOI: $10.15190 /$ d.2015.43

In type 1 diabetes, insulin-secreting $\beta$-cell replacement by islet transplant from cadaveric organ donor pancreas, carried out for decades, is potentially a curative therapy. Unfortunately, the function of the transplanted $\beta$-cell in the transplanted islets progressively declines, due in part to impairment in their secretory function. Studies report $^{1-3}$ that, as early as one week following islet transplant, insulin secretion is significantly lower then in freshly isolated islets, and greatly reduced at 40 weeks. Furthermore, the current islet isolation protocols are unable to recover all islets from the entire pancreas, further limiting the number of transplanted islets, resulting in an insufficient $\beta$-cell mass for the recipient.

Nearly 20 years ago, permanent cup-shaped lipoprotein structures at the cell plasma membrane, called "porosomes", were discovered (see schematic representation of the porosome in Fig 1), where secretory vesicles transiently dock and fuse to expel intravesicular contents from the cell. Porosomes are present in all secretory cells, from the digestive enzyme-secreting pancreatic acinar cells, to the hormone-releasing growth hormone and insulin-secreting cells, mast cells, chromaffin cells, hair cells of the inner ear, and in neurons secreting neurotransmitters ${ }^{4,5}$. Porosomes have been immunoisolated from a number of cells including the exocrine pancreas and neurons, biochemically characterized, and functionally reconstituted into artificial lipid membrane ${ }^{5}$. A large body of evidence has accumulated on the role of porosome-associated proteins on cell secretion and secretory defects, including neurotransmission and neurological disorders $^{6}$. In a recent study, the porosome complex in mouse insulinoma Min6 cells was isolated, its proteome determined ${ }^{7}$, and the isolated porosome was functionally reconstituted into live Min6 cells ${ }^{8}$.

The discovery of the porosome complex has come full circle: from elucidation of its structure and dynamics in secretory cells examined, to its structural and functional reconstitution into artificial lipid membranes and secretory cells, and the identification of its important participation in health and disease 


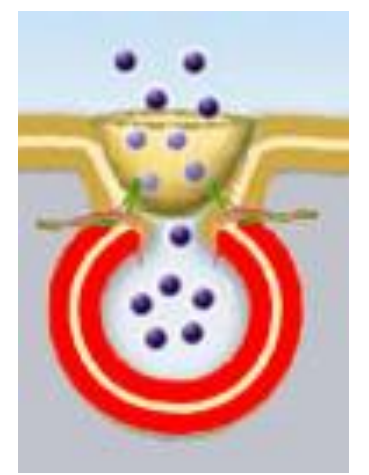

Mass spectrometry on isolated Min6 porosome demonstrates the presence of 30 core proteins including SNAREs, the heat shock protein Hsp90, the calcium-transporting ATPase type $2 \mathrm{C}$, and the potassium channel subfamily $\mathrm{K}$ member 2 . In a recently published study ${ }^{8}$, isolated Min6 porosomes reconstituted into live Min6 cells demonstrate augmented levels of porosome proteins and a consequent increase in the potency and efficacy of glucose-stimulated insulin secretion. Elevated glucose-stimulated insulin secretion $48 \mathrm{~h}$ post reconstitution, reflects the remarkable stability and viability of reconstituted Min6 porosomes, documenting for the first time the functional reconstitution of native porosomes into live cells and their potential utility in therapy. However, further studies in an animal model will be required to determine the viability and function of transplanted islets reconstituted with the isolated insulin-secreting porosome complex. It is important to note that the porosome discovery has far reaching implications in health and medicine. For example, mass spectrometry on isolated porosomes from human lung epithelial cells demonstrates interaction between the cystic fibrosis trans-membrane conductance regulator (CFTR) and the porosome complex in human airways epithelia, shedding light on the possible regulatory role of CFTR on the quality of mucus secretion via the porosome complex ${ }^{9}$. Reconstitution of functional porosome complex isolated from cadaveric human lung epithelia could potentially ameliorate secretory defects in patients with the CFTR disease. Similarly, post-traumatic stress disorder or PTSD in part attributed to loud explosions, or continuous white noise, has been demonstrated to result in memory loss and anxiety, among others health detriments. Ultrastructure studies on the neuronal porosome complex in rats subjected to continuous white noise report alterations in the neuronal porosome morphology, hence its chemistry ${ }^{10}$. Therefore, the important discovery of the porosome complex has come full circle: from elucidation of its structure and dynamics in all secretory cells examined, to its isolation, determination of its chemistry, its structural and functional reconstitution into artificial lipid membranes, to finally its functional reconstitution into live secretory cells, and the identification of its important participation in health and disease, resulting in a paradigm-shift in our understanding of the secretory process. Great future applications await the pioneering discovery of the porosome complex, analogous to the proteasome, ribosome, the lysosome, or the nuclear pore complex.

Keywords: Porosome, Insulin Secretion, Islet Transplant, Diabetes;

\section{Acknowledgements:}

This work was supported by the United States Department of Agriculture, National Research Initiative Grants by USDA NRI 2003-35206-12817 and 2005-3560415618 (L.L.A.), the Iowa Agriculture and Home Economics Experiment Station, Ames, Iowa and by Hatch Act and State of Iowa funds.

\section{Conflict of Interest:}

The author has no conflict of interest to declare.

\section{References:}

1. Rickels MR, Schutta MH, Markmann JF, Barker CF, Naji A, Teff KL. beta-Cell function following human islet transplantation for type 1 diabetes. Diabetes 54:100-106, 2005.

2. Meier JJ, Hong-McAtee I, Galasso $\mathrm{R}$, et al. Intrahepatic transplanted islets in humans secrete insulin in a coordinate pulsatile manner directly into the liver. Diabetes 55:2324-2332, 2006. 
3. Täljedal IB, Shi CL, Rooth P. Functional aspects of mouse islets transplanted to the kidney. Diabetologia 37(Suppl. 2):S112-S116, 1994.

4. Jena BP. Porosome discovered nearly 20 years ago provides molecular insights into the kiss-and-run mechanism of cell secretion. J Cell Mol. Med. J. 2015 May 28. PMID: 26033351, 2015.

5. Jeremic A, Kelly M, Cho S-J, Stromer MH, Jena BP. Reconstituted fusion pore. Biophys. J. 85:20352043, 2003.

6. Naik AR, Lewis KT, Jena BP. The neuronal porosome complex in health and disease. Exp. Biol. Med. (Maywood) OnlineFirst, published on August 11, 2015 as doi:10.1177/1535370215598400, 2015.

7. Rajagopal A, Kulkarni S, Lewis KT, Chen X, Maarouf A, Kelly CV, Taatjes DJ, Jena BP. (2015). Proteome of the insulin-secreting Min6 porosome complex: Involvement of Hsp90 in its assembly and function. Journal of Proteomics 114:83-92, 2015.
8. Naik AR, Kulkarni S, Lewis KT, Taatjes DJ, Jena BP. Functional reconstitution of the insulin-secreting porosome complex in live cells. Endocrinology 2015 Nov 2:en20151653.

9. Hou X, Lewis KT, Wu Q, Wang S, Chen X, Flack A, Mao G, Taatjes DJ, Sun F, Jena BP. Proteome of the porosome complex in human airways epithelia: Interaction with the cystic fibrosis transmembrane conductance regulator (CFTR). Journal of Proteomics 96:82-91, 2013.

10. Japaridze NJ, Okuneva VG, Qsovreli MG, Surmava AG, Lordkipanidze TG, Kiladze M, Zhvania MG. Hypokinetic stress and neuronal porosome complex in the rat brain: the electron microscopic study. Micron 43:948-63, 2012.

DISCOVERIES is a peer-reviewed, open access, online, multidisciplinary and integrative journal, publishing high impact and innovative manuscripts from all areas related to MEDICINE, BIOLOGY and CHEMISTRY; C 2015, Applied Systems 